\title{
Syntactics, Cognition and Compositional Semantics
}

\author{
Boris Ju. Norman \\ Belarusian State University \\ 31, Karl Marks str., 220050 Minsk, Belarus \\ Ural Federal University \\ 51, Lenin av., 620000 Ekaterinburg, Russia
}

\begin{abstract}
The object of the article is word semantics and its realization in the immediate context. The goal and the innovative component of the study is the analysis of the problem in the light of cognitive linguistics. We proceed from the assumption that the lexical meaning of a word contains a component responsible for its entry into the text. This component involves searching for lexical partners of the word in the syntagmatic chain. The semes participating in this process are actualized - they must get into the bright field of consciousness. The classical manifestation of this connection is the so-called semantic agreement (собака лает 'a dog barks', бурый медведь 'a brown bear', волосы дыьом 'hair (stands) on end', etc.). We use examples from Russian literature to demonstrate that when a non-typical (non-standard) word combination is formed, the concepts get intersected (mixed). The examples, such as салопишущий костюм 'a selfwriting suit' or жаркая робость 'hot timidity', expand a person's cognitive horizons making the individual accustomed to a different (virtual) reality. The background and guarantor of this combinatorial process is the so-called "common sense" based on the native speaker's previous experience. The result of the study is the presentation of five special situations manifesting the relationship between the word and its text partners: polysemantic words, phraseological units, introduced (embedded) meanings, additional connotations and a surprise effect. The author provides examples of the pressure (influence) of text memory on the speaker when selecting a necessary word and considers the idea of the predicative nature of the compatibility of lexemes. The article justifies the emergence of compositional semantics as a special direction in modern linguistics and demonstrates some of its results (based on the Russian language).
\end{abstract}

Keywords: cognition, syntactics, compositional semantics, lexical meaning, word compatibility, connotation

\section{For citation:}

Norman, Boris Ju. (2019). Syntactics, Cognition and Compositional Semantics. Russian Journal of Linguistics, 23 (3), 714—730. doi: 10.22363/2312-9182-2019-23-3-714-730. 


\title{
Синтактика, когниция и композиционная семантика
}

\author{
Б.Ю. Норман \\ Белорусский государственный университет \\ пр. Независимости, 4, Минск, 220050, Беларусь; \\ Уральский федеральный университет \\ пр. Ленина, 51, Екатеринбург, 620000, Россия
}

\begin{abstract}
Аннотация
Объектом статьи является семантика слова и ее реализация в ближайшем контексте. Цель и новаторский компонент исследования - анализ проблемы с точки зрения когнитивной лингвистики. Исходное положение: в лексическом значении слова есть составляющая, отвечающая за его вхождение в текст. Она включает в себя поиск лексических партнеров слова по синтагматической цепи. Участвующие в этом процессе семы актуализируются — они должны попасть в светлое поле сознания. Классическое проявление этой связи — так называемое семантическое согласование (собака лает, бурый медведь, волосы дыбом и т.п.). На материале русской художественной литературы показано, что при образовании нетипичного (нестандартного) словосочетания происходит пересечение (смешение) концептов. Примеры типа самопишущзий костюм или жаркая робость расширяют когнитивные горизонты человека, приучают его к иной (виртуальной) действительности. А в качестве фона и гаранта данного комбинаторного процесса выступает так называемый «здравый смысл», опирающийся на предшествующий опыт носителя языка. Результатом работы является выделение 5 особых ситуаций, воплощающих в себе отношения слова и его текстовых партнеров: это многозначные слова, фразеологические сочетания, наводящееся (привнесенное) значение, дополнительные коннотации и эффект неожиданности. Приводятся также примеры давления (влияния) текстовой памяти на говорящего в процессе выбора нужного слова, рассматривается идея предикативной природы сочетаемости лексем. Мотивируется появление особого направления в современном языкознании - композиционной семантики и демонстрируются (на материале русского языка) некоторые его результаты.
\end{abstract}

Ключевые слова: когниция, синтактика, композиционная семантика, лексическое значение, сочетаемость слов, коннотация

Для цитирования:

Норман Б.Ю. Синтактика, когниция и композиционная семантика // Russian Journal of Linguistics. 2019. T. 23. No 3. C. 714-730. doi: 10.22363/2312-9182-2019-23-3-714-730.

\section{1. Введение}

Понятие синтактики как компонента содержания знака было, как известно, введено в науку американским лингвистом Ч. У. Моррисом, одним из основателей семиотики (Моррис 1983: 42-43, 48-50 и др.). Позже эта идея стала приобретать зримые черты в виде лингвистического понятия сочетаемости, или комбинаторики. Стали появляться словари сочетаемости (первый заметный опыт на материале русского языка - см.: (Словарь сочетаемости 1983)); одновременно с этим разрабатывалось понятие устойчивой сочетаемости слов (в первую очередь применительно к фразеологическим единицам).

Одно из открытий, которое было сделано, так сказать, попутно, - это явление семантического согласования, см.: (Гак 1972: 380). Это значит, что объединяющиеся 
в словосочетание слова очень часто содержат в себе общие (одинаковые) семы. Например, сочетания собака лает, крапива жжется, петух кукарекает, штопать носки, читать книгу, волосы дыбом, кепка набекрень, глаза навыкате, пьяный вдрабадан, бурыц̆ медведь и т.п. весьма устойчивы в русскоязычном сознании. И это их свойство поддерживается общими семами: информация как бы дублируется в членах словосочетания. Что такое, например, собака в обыденном сознании? Это животное, которое лает, стережет дом, друг человека и т.д. Что такое лаять? Это издавать звуки, которые обычно производит собака. В самом значении каждого слова как бы заложен второй компонент словосочетания. Вопрос только в степени устойчивости таких сочетаний.

Ниже предпринимается попытка выделить несколько языковых ситуаций, связанных с влиянием значения соседних слов на значение данной лексемы. Это имеет прямое отношение к активно дискутируемой ныне проблеме приоритета: значение слова создает контекст или же оно само порождается контекстом? (см.: Кечкеш 2014: 7-10).

\section{1. Употребление многозначного слова}

В случае, если слово многозначно, то его сочетаемость со словами-партнерами позволяет выбрать одно, необходимое в данном случае значение. Апелляция к контексту позволяет на практике снять остроту теоретической проблемы разграничения слов-омонимов и лексико-семантических вариантов многозначного слова. Приведем сначала известный пример. Русские выражения гусь в яблоках и конь в яблоках содержат в своем составе идентичную словоформу в яблоках. Но различный смысл этих двухкомпонентных выражений (в первом случае - «праздничное блюдо», во втором - «масть лошади») подразумевает и различное значение входящего в их состав слова яблоко. Разница в когнитивном контенте передается благодаря сочетаемости лексемы яблоко с названиями разных животных: это гусь и конь.

Приведем теперь более свежий пример - из юмористического рассказа:

(1) - А где их [чемпионов - Б.Н.] выращивают?

- У Анастасии Голубиовой. Вы видели ее, красивая такая дама в сапогах на платформе...

- Железнодорожная платформа, идейная платформа, теперь уже сапоги на платформе, - сказал папа (С. Шатров. Из рассказов о Васюковых).

Персонаж рассказа «разводит» значения слова платформа при помощи его окружений, и это не такая уж редкая в речевой практике ситуация. Синтаксический партнер слова помогает опознать и подтвердить его собственное значение.

Сама идея связи значения слова с его окружением достаточно стара, но попрежнему привлекает внимание исследователей. Так, взаимообусловленность лексической семантики слова и его комбинаторики составляет важную часть концепции генеративного лексикона Джеймса Пустейовского. Говоря о «новых контекстах, придающих слову новые значения», ученый приходит к выводу, что «композиционность есть требование исчисления смыслов слова» (Pustejovsky 1996: 60). 
С одной стороны, избирательность лексемы по отношению к ее партнерам составляет условие правильности высказывания. Еще М. Бирвиш в своей известной статье 1972 года писал: «Ограничения подобного рода называются „селекционными ограничениями“, так как они указывают, какие лексические элементы могут быть выбраны для построения семантически правильного сочетания двух или более синтаксически связанных лексических элементов» (Бирвиш 1981: 183).

С другой стороны, партнер по сочетаемости выступает как дифференциальный признак слова, в некотором смысле - как «продолжение» его значения. «Сквозные» для сочетающихся слов семантические признаки, заложенные в сознании носителя языка, составляют часть лексической семантики каждого из слов и предопределяют функционирование последних в конкретных дискурсивных условиях. Приведем еще одну цитату из статьи М. Бирвиша: «Мы должны знать, например, что слово group 'группа' в математических текстах имеет одно значение, в социологических дискуссиях — другое, в каждодневной речи - третье» (Там же: 198).

Наглядно такая уточняющая роль контекста выступает в случаях, когда адресат сталкивается с неосвоенными заимствованиями, агнонимами и прочей малознакомой лексикой. В следующем примере отражены впечатления подростка от «взрослого» слова взятки:

(2) Я не очень хорошо понимал, что такое взятки, я только помнил, что их зачем-то дают и берут и что это ужсасно плохо и стыдно (А. Вайнер, Г. Вайнер. Гонки по вертикали).

Определение значения слова «через контекст», благодаря контексту — практика, известная любому человеку, который, скажем, читает произведение на плохо знакомом языке. И, вместе с тем, это, очевидно, естественный путь освоения новой лексики в онтогенезе.

\section{2. Сигнализация семантического сдвига}

Если сочетаемость слова (так же, как его частотность) меняется, то это свидетельствует о сдвигах в его лексической семантике, см.: (Никифорова 2006; Влавацкая 2014 и др.). Очень характерны данные эволюционные процессы для лексики, относящейся к сфере идеологии, внешней и внутренней политики, общественных отношений.

Вертикаль власти, шаговая доступность, группа риска, бюджетная сфера, соотношение «цена - качество», ценовой сегмент, признательные показания, база данных, черный пиар, гибридная война, облачные технологии, в одном флаконе и т.п. - вот сочетания, которые были необычными для входящих в них слов и, вместе с тем, стали маркерами социальных изменений, происходящих в России с конца XX века.

После распада Советского Союза на территории Российской Федерации региональные органы власти и чиновники стали присваивать себе невозможные до тех пор обозначения правительство, министерство, министр. Появились словосочетания вроде правительство Томской области, министерство образования 
Красноярского края, министерство здравоохранения Ленинградской области, министр финансов Саратовской области, министр культуры Омской области и т.п. Это, с одной стороны, говорит об объективной децентрализации власти в России, а, с другой стороны, - о стремлении региональных чиновников словесно повысить свой служебный статус. Такая девальвация содержания лексем тут же отразилась на их сочетаемости.

Если понятие, заключенное в слове, определенным образом концептуализируется, т.е. повышает свою значимость в системе общественных символов, то это, естественно, находит свое отражение в лексической сочетаемости. Например, одним из ключевых понятий классической психологии всегда была память. В соответствии с этим, Словарь сочетаемости фиксирует такие определения к данному слову, как хорошая, прекрасная, отличная..., слабая, отвратительная, плохая..., зрительная, слуховая, механическая и т. д. В качестве объекта существительное память выступает при глаголах развивать, тренировать, упражнять, напрягать, потерять (Словарь сочетаемости 1983). Но когда память стала частью электронновычислительных машин и слово вошло в ряд важнейших терминов информатики, это тут же сказалось на его сочетаемости: компьютерная память бывает оперативная и постоянная, буферная, матричная, многоуровневая и т.д., ее можно увеличивать или расширять...

Подобные сдвиги произошли за последние десятилетия в семантике и в комбинаторике многих русских слов, например: телефон, химия, косяк, тормоз, откат, элита и др. Еще один пример. Медицинский термин геморрой стал в конце $\mathrm{XX}$ века приобретать вторичное значение 'неприятности, тягостные хлопоты'. В общей массе словоупотреблений, представленных в НКРЯ (211 вхождений, на 12.07.2018), употребление лексемы геморрой в переносном значении составляет примерно 18\%. И если, по данным НКРЯ, к началу ХХ века частота употребления данного слова постепенно снижалась, то к концу XX века она вновь начала расти именно благодаря таким контекстам, как тот ещзе геморрой, лииний геморрой, не оберешься геморроя, геморрой с запчастями и т.п. - см.: www.ruscorpora.ru. Все подобные контексты указывают на новое, переносное значение слова, оказавшееся востребованным в жизни общества. Не будем здесь говорить о том, что при этом может «сдвинуться» и словоизменительная парадигма лексемы, и ее словообразовательные потенции.

\section{2. Наведение окказионального значения}

В таком случае слово-партнер по синтагматической цепи помогает оправдать и разъяснить появление у лексемы необычного (в принципе отсутствующего у нее) значения. Иными словами, слушающий «расшифровывает» это окказиональное значение главным образом благодаря соседним лексемам. Два примера из художественных текстов.

(3) Такой же эдельвейс бежал под пулеметным огнем в Киеве купить кружево на блузку (Тэффи. Воспоминания. Житье-бытье).

Существительное эдельвейс здесь обозначает женщину, в самых тяжелых и опасных условиях сохраняющую свою женственность (ранее в тексте есть объяснение такой окказиональной номинации). Но сочетание эдельвейс бежал 
(купить) уже подготавливает читателя к тому, что перед ним - описание поступка человека, а не жизнедеятельности цветка.

(4) И они выскребают снисходительного Познера из сусека, пропитанного веселым запахом местных напитков и женских духов (М. Веллер. Легенды Арбата).

Слово сусек 'закром, помещение для хранения зерна и муки' употреблено здесь в значении 'комната, кабинет'. (Спровоцировано такое словоупотребление, скорее всего, глаголом выскребать, ср. в русской сказке «Колобок»: по амбарам помети, по сусекам поскреби.)

Вообще же изначальная мотивировка окказиональной номинации может быть самая разная, и со временем ей свойственно затемняться, ср. ситуацию в семье поэта Жуковского, описанную в сборнике «Русский литературный анекдот»:

(5) Их слуга Лука часто сидел, как турка, и кроил себе панталоны. Государь проходил мимо к Карамзиным, не замечая этого. "Император, - говорил Жуковский, - видел что-то белое и думал, что это летописи». У нас завелась привычка панталоны звать летописями.

Понятно, что имеются в виду контексты типа Надень летописи или Где мои летописи? - и семантический окказионализм приобретает тут функцию особого маркера - для данной языковой личности или узкого круга лиц. Поясним: подобные окказиональные названия имеют очень ограниченное хождение - как правило, в малых коллективах типа семьи или корпоративной (производственной) группы. В литературе и в нашей картотеке зафиксированы, в частности, такие уникальные «домашние» номинации, как Пиночет 'холодильник', Иглесиас 'салат оливье', Харрисон 'жена, супруга', фараон 'рюкзак', микроволновка 'маршрутное такси', Снегурочка 'телефонный аппарат' и т.п. (см. также: Современный русский язык 2003: 311-323). Только соответствующий контекст (бытовой и словесный) позволяет семантизировать данные номинации правильным образом. Для членов малой группы (семьи и т. п.) данные названия не просто привычны, но служат своего рода шиболетами, паролями, позволяющими вербально отличить «своего» от «чужого».

Возвращаясь к обозначенной выше проблеме: «значение ли слова создает соответствующий контекст или же контекст определяет значение слова», следует признать наличие между этими двумя факторами взаимной обусловленности. Однако нельзя также не видеть, что в отдельных случаях значение может быть «навязано» слову, привнесено в него извне. Тогда роль контекста оказывается приоритетной. В терминах структурной семасиологии в таких случаях говорят о наведении сем: «Наводятся семы, отсутствующие в системном значении слова. Наведенные семы относятся к разряду окказиональных» (Стернин 1985: 118). Действительно, как в рассмотренном случае, - летописи и панталоны обладают общим признаком 'белый цвет', однако этого недостаточно для системного семантического переноса. Впрочем, при всей разовости, уникальности подобных наименований возникновение их мотивировано ситуацией и в этом смысле не случайно. Внедрение в значение слова чужих, посторонних компонентов оправдывается планируемым дополнительным эффектом - эстетическим, людическим, корпоративным и т.п. 


\section{3. Десемантизация слова в составе фразеологического сочетания}

В качестве частного случая проявления правил лексической сочетаемости следует рассматривать устойчивые (фразеологические) сочетания слов. Синтактический аспект значения оказывается здесь чрезвычайно важным, вплоть до того, что одно из слов-компонентов (или все они) может терять свое собственное значение. Примерами могут послужить русские выражения зарубить на носу, втирать очки, верста коломенская, на кривой козе не объехать и т. п. Это объясняет и появление в составе фразеологизмов отмерших форм (некротизмов), ср.: ничтоже сумняшеся, почить в бозе, турусы на колесах, притча во языцех и т.п. В таких случаях смысл целого как бы распределяется по нескольким лексемам сочетание лишает слова его отдельного значения.

Русский язык приучает человека к тому, что летучие мыши - это «мыши», растительное масло - это «масло», баклажанная икра - это «икра», а крабовые палочки - это изделие из краба (хотя на деле все это совсем не так). Перед нами случаи своего рода семантического идеализма, но в обыденной речевой практике это никого не смущает.

Готовые коллокации (выражения, словосочетания) постоянно присутствуют в сознании человека в качестве своего рода словесного «гула», см.: (Гаспаров 1996: 105-109 и др.) и иногда вынуждают его употребить целое словосочетание там, где в нем нет никакой необходимости. Так, в следующем контексте слово голубь «вытягивает» словоформу мира без всякой смысловой надобности, а лишь в силу устойчивости выражения:

(6) - ...Один раз искал, искал - показалось, кто-то с улицы зовет, шагнул с балкона, и все, не вернулся.

- Разбился?

- Ну, с девятого этажа - шутка в деле! Он же не голубь мира. Когда летел, успел, правда, крикнуть: «Эй!» (В. Шукшин. Вянет, пропадает).

Точно так же в цитате из рассказа М. Веллера появление слова остров спровоцировано известным выражением остров сокровищ; на деле же никакого острова как денотата в данной ситуации не было.

(7) И вот, скромно и горделиво бормоча комплименты своим способностям, как взлетевший на насест петух, он сноровисто сгребает в бочонок свой остров сокровищ: стальную арматуру, мотки медной проволоки, паяльники, гаечные ключи и пассатижи. Килограммов полтораста (М. Веллер. Легенды Арбата).

Персонаж одного рассказа Е. Попова употребляет в своей речи выражение охотиться на лис. Он говорит:

(8) Tы бы вместо того, чтоб на «лис» охотиться, пришел былучше ко мне и все исправил либо оплатил повреждения, а то - пожечь пожег, а как ремонтировать - фью и хвостом вильнул, сукин ты сын (Е. Попов. Живой живущий человек).

Но в конце, в примечаниях, автор рассказа комментирует:

(9) «Охота на лис» - состязание по радиоориентированию на местности. К данной ситуачии рассказа никакого отношения не имеет, персонаж употребляет этот термин неправильно, понасльике (Там же). 
Перед нами, таким образом, - очередные примеры «давления» текста (языковой памяти) на человека. Подобные случаи также правомерно рассматривать как свидетельство десемантизации слова в составе устойчивого словосочетания.

Великому немецкому философу Х.-Г. Гадамеру принадлежит афоризм: «Скорее язык говорит нами, чем мы говорим языком» (Gadamer 1975: 439). Последние из приведенных примеров вполне подтверждают эту максиму. Говорящий далеко не всегда находит в себе силы сопротивляться «гулу языка», и в результате на выходе появляются фразы, не мотивированные речевой ситуацией. Но эта сила языковой инерции может получить и более глубокую лингвистическую интерпретацию. Если согласиться с Ю.Н. Карауловым в том, что языковая способность носителя языка (воплощающаяся в ассоциативно-вербальной сети) - «это постоянная готовность к предицированию, к созданию синтаксем, каждая из которых, представляя собой диссипативную структуру, стремится обрести более четкие очертания, став в перспективе частью завершенного синтаксического целого» (Караулов 1999: 37), то самое простое для говорящего решение этой задачи - это подыскать в памяти известные, уже использовавшиеся фрагменты текстов. И хотя данный вывод ученого основывается на материале ассоциативных экспериментов, т.е. методики в некотором смысле искусственной, условной, представляется, что его можно распространить и на естественный процесс речепорождения. Процитируем другое место из упомянутой работы: «Разбуженная предложенным ему стимулом иллокутивная сила говорящего (активность) толкает его к предицированию, а память услужливо приводит тотчас же его личный (или принадлежащий его референтной группе, целиком одобряемый и принимаемый им) шаблон, прецедент, извлеченный из типичного для него текста, из его текста, им когда-то произведенного и только ему принадлежащего» (Там же: 114). Естественно, речь идет о взрослой личности, с более или менее сформировавшимся речевым опытом, т. е. накопленной в памяти суммой текстов.

\section{4. Появление дополнительных коннотаций}

Слово-партнер может, не меняя основного значения данного слова, придавать ему особую коннотацию: эмоциональную, оценочную, идеологическую, стилистическую и т. п. Фактически это тоже наведение семы, но - коннотативной.

Характерным поводом для дальнейших рассуждений послужит нам величайшее историческое событие XX века - революция в России в октябре 1917 года. Для граждан первого в мире социалистического государства, которое просуществовало более 70 лет, совершенно естественным было выражение «Великая Октябрьская сочииалистическая револючия свершилась». Но прошло время, распался Советский Союз, изменился общественный строй в России, началась переоценка ценностей, и историческое событие кое-кто стал называть октябрьским переворотом. Стали писать: «В России в октябре 1917 года произошел переворот, в результате которого к власти пришла партия большевиков».

И в данном случае нас интересует чисто лингвистическая проблема: почему о революции говорили - свершилась, а о перевороте - произошел? 
Обратимся сначала к семантике слова революичия. Современный словарь дает следующее определение:

РЕВОЛЮЦИЯ (от лат. revolutio - переворот) - 1. Коренной переворот во всей социально-экономической структуре общества, приводящий к смене общественного строя... (БТСРЯ).

Можно ли утверждать, что в значении этого слова заведомо содержится положительная оценка? Иными словами, революция - это явно лучше, чем эволюция (поступательное движение без скачков)? Судя по словарному толкованию, семантика данного существительного нейтральна или даже амбивалентна. Знаменательно, что в Толковом словаре Владимира Даля еще за пару десятилетий до событий 1917 года дается:

Революция - переворот, внезапная перемена состоянья, порядка, отношений; смута или тревога, беспокойство (Даль 1912).

Очевидно, в этом определении (в котором революция приравнивается к перевороту) присутствует скорее отрицательная, чем положительная окраска. Напомним также, что одним из значений латинского префикса re- было «возврат, движение назад» - в русском языке есть такие слова, как регресс, редукция, penamриация, реституция и т. п. Быть революции в этом ряду — не очень почетно...

Переворот же, с точки зрения современной лексикографии, мало чем отличается от революции - может быть, только своим масштабом:

ПЕРЕВОРОТ - 1. Резкий перелом, коренное изменение в развитии, течении, ходе чего-л.;

2. Коренное изменение существующей общественно-политической системы... (БТСРЯ).

Но для того, чтобы подчеркнуть положительные, благотворные свойства этого исторического события, надо было «зачеркнуть» в значении слова революиия негативные семы («тревога», «смута» и т.п.) и «выпятить» семы позитивные («развитие», «перемены»). На службу идеологии была поставлена сочетаемость слов. Произойти - слово нейтральное по своей стилистике. Можно сказать: произошел несчастный случай, произошло удивительное событие, всё произошло очень быстро... А свершиться - глагол высокого стиля, он применяется к событиям великим, эпохальным, судьбоносным:

(10) Судьбы свериился приговор... (М.Ю. Лермонтов. Смерть поэта).

Таким образом, употребление в качестве партнера слова революция сказуемого свершилась было призвано поддержать имидж революции средствами русского языка. В конце же XX века, вместе с девальвацией исторического события, изменилась и сочетаемость существительного: о перевороте стали говорить произошел.

Нечто подобное, даже в более явной форме, произошло со словом залп.

Как известно, стоявший на реке Неве крейсер «Аврора» 25 октября 1917 года произвел холостой выстрел из орудия, послуживший сигналом к штурму Зимнего дворца (где заседало Временное правительство). Обратимся к словарю.

ВЫСТРЕЛ - Выбрасывание пули, снаряда из ствола огнестрельного оружия... (БТСРЯ). 
Однако выстрел крейсера «Аврора» вскоре был назван залпом. В учебниках так и писали: «Залп Авроры возвестил новую эру в истории человечества...». Согласно тому же словарю,

ЗАЛП - одновременный выстрел из нескольких орудий, ружей (БТСРЯ).

Фактически никакого залпа не было. Крейсер дал одиночный сигнальный выстрел из носового орудия. Почему же в сознание носителей русского языка так прочно вошло словосочетание залn Авроры? Потому что в значении слова залn, в отличие от слова выстрел, присутствует элемент «возвышенное». И ради этой стилистической детали пришлось, в общем-то, пойти на некоторую неточность (чтобы не сказать - языковую ложь).

Пример из современной поэзии. В стихотворении Е. Евтушенко «Дай Бог» читаем:

(11) Дай Бог не вляпаться во власть...

Само по себе слово власть - нейтральное и амбивалентное по своей семантике. В его толковании ничего плохого не просматривается:

ВЛАСТЬ - 1. Право и возможность распоряжаться, повелевать, подчинять своей воле... (БТСРЯ).

Но глагол вляпаться в русском языке обладает сниженной, неодобрительной коннотацией: вляпаться можно только во что-то плохое:

ВЛЯПАТЬСЯ - Разг.-сниж. 1. Ввалиться, вступить, попасть во что-л. грязное, пачкающее... (БТСРЯ).

Получается, что аксиологическая и эмоционально-экспрессивная окраска глагола вляпаться передается лексеме власть, наводится на нее.

Еще пример. В современной повести читаем:

(12) У моей подруги Людки Самохиной был день рождения. Само собой, она решила его отметить, ну и назвала гостей с три короба, но не к себе в квартиру, а в студию (Т. Полякова. Чудо в пушистых перьях).

Наречное выражение с три короба прочно увязывается в сознании носителя русского языка со словом врать. Врать же - явно негативный по своей семантике глагол. Отсюда читатель делает вывод, что описываемая ситуация (приглашение гостей) либо же сами гости оцениваются писателем отрицательно. Одно слово (выражение с три короба) перенесло свою отрицательную коннотацию на другие (назвать гостей).

\section{5. Расчет на эффект неожиданности}

Наконец, бывает, что нарушение стандартной сочетаемости используется как стилистический прием. Речь идет о ситуации так называемого остранения текста (термин В. Шкловского), когда читатель или слушатель сталкивается с мгновенным эффектом обманутого ожидания, достигаемого языковыми средствами.

Например, на фоне стандартных и привычных оборотов глаза навыкате, ударить наотмашь, ночь напролет мы встречаем в текстах сочетания зубы навыкате, одеваться наотмашь, программу напролет:

(13) Похож дежурный на оглушенного бобра: зубы навыкате и шерсть мокрая (М. Веллер. Легенды Арбата). 
(14) Незамужняя девушка одевается наотмашь («Комсомольская правда», 14.10.2010).

(15) Дамы обращаются к миллионам зрителей на южнорусском диалекте. Когда варят борщ, всю программу напролет говорят «свеклА»- причем и гости в студии, поддавшись обаянию ведущих («Комсомольская правда», 08-14.11.2012).

Как известно, для некоторых писателей употребление нестандартных словосочетаний составляет отличительную языковую черту их произведений. Например, в «Мастере и Маргарите» М. Булгакова мы находим такие обороты, как клетчатый гражданин, сиреневый клиент, самопишущий костюм, огненный борщ, бессонный этаж, бальковое бревно, доедаемая малокровием девушка, желтобрюхая грозовая туча и т. п. Любопытно, что подобные выражения встречаются преимущественно в той части романа, где описывается Москва 20-х годов; в «исторической» же части подобных новаций практически нет.

Склонность к оригинальной комбинаторике лексем еще более характерна для прозы Владимира Набокова. Так, в повести «Король, дама, валет» встречаются сочетания цุиферблат, полный отчаяния, презрения и скуки; прыщеватая жизнь иколь, мохнатые дольки апельсинов, пряное мотовство, бородавка, как репейник, на щекке; обветшалая собачка, велосипед с завернутыми лапками, хитрый электрический ток, жаркая робость и т.п. А вот собственноручное признание мастера слова: «Мне нравилось - и до сих пор нравится - ставить слова в глупое положение, сочетать их шутовской свадьбой каламбура, выворачивать наизнанку, заставать врасплох» (В. Набоков. Отчаяние).

Проще всего было бы объяснить появление ломающих языковую традицию словосочетаний стремлением говорящего «оживить» текст, придать ему бо́льшую экспрессию (не случайно основная масса таких случаев встречается именно в художественной литературе и публицистике). Но у нетипичной сочетаемости есть и своя психологическая и информационная подоплека. Устойчивое словосочетание опознается и осмысляется адресатом быстрее, чем нетипичное, однако его информационная ценность ниже последнего, и в этом смысле оно тривиально. Окказиональные же словосочетания «создают качество совершенно новое не только с формальной, но и с концептуальной точки зрения» (Turula 2007: 507). Как показал Д.Дж. Аллертон, при всей условности, произвольности выбора лексического партнера в речевой цепи, он (этот выбор) может быть объяснен с когнитивистских позиций (Allerton 1990: 28-30). Наложение друг на друга, взаимопересечение (англ. blending) ментальных пространств порождает в сознании новые феномены. Речь тем самым идет о расширении познавательного кругозора носителя языка, об активизации его внимания, фантазии и креативного потенциала.

Вспомним еще очень уместные в данном контексте слова Эдварда Сепира: «Поставим рядом два выбранных наудачу простых английских слова. < ..> Оказывается психологически невозможным услышать или увидеть эти два слова вместе, не постаравшись хоть сколько-нибудь связным образом их осмыслить» (Сепир 1993: 72). И далее американский лингвист перебирал возможности смысловой интерпретации конкретного сочетания слов... 


\section{6. Развитие композиционной семантики}

Осмысление разнообразных речевых случаев, подобных описанным выше, привело к тому, что в границах семасиологического подхода сформировалось теоретическое направление композиционной (или комбинаторной) семантики.

Композиционная семантика - новое направление в лингвистике, которое занимается изучением комплексных знаков языка, местом значения отдельной единицы в составе значения целого, соотношением семантики сочетающихся друг с другом единиц. Это направление позволяет по-новому взглянуть как на семантическую структуру слова, так и на место лексических групп (синонимов, антонимов, гипо- и гиперонимов) в общей системе языка. В частности, сопоставление семантики сочетающихся прилагательных и существительных позволило наметить типовые пути развития метафорических значений, см.: (Aarts, Calbert 1979). А в статье С. Джонса и соавторов продемонстрировано, как контекст влияет на выбор антонима к английскому многозначному слову dull («глупый», «тусклый», «пасмурный», «скучный», «вялый» и т.д.) (Jones et al. 2007: 139-141). Особый интерес к данной проблематике подогревается исследованиями в смежных областях - формальной семантики и компьютерных технологий, см.: (Sweetser 1999; Asher 2011; Jacobson 2014 и др.). В России различные аспекты композиционной семантики разрабатываются в трудах Е.С. Кубряковой, Н.В. Юдиной, М.В. Влавацкой и др.

Основополагающими для композиционной семантики являются две идеи. Первая: значение слова содержится не только в нем самом, но и в его партнерах по речевой цепи. Доводя эту мысль до абсолюта, можно было бы сказать, что значение слова находится за его пределами - в соседних словах, в контексте. Но это означало бы определять одно неизвестное через другое. И такой позитивистский взгляд был бы для лингвистов малопродуктивным.

Поэтому не менее важной представляется вторая идея. Ее можно сформулировать так: при выборе нужного значения и формировании смысла целого адресат обращается к своей памяти — языковой и энциклопедической (о разграничении языковой и энциклопедической информации см., например: Рахилина 2000: 22-26). Накопленный там опыт играет роль решающего критерия, способного «переварить» любые отклонения в сочетаемости.

Плодотворность композиционного подхода уже была в свое время продемонстрирована дериватологами. Было показано, что семантический потенциал словообразовательной модели реализуется через комбинаторику морфем, однако упирается при этом в наши «знания о мире». Так, суффикс -ник может участвовать в русском языке в образовании названий посуды (кофейник, чайник, молочник...), а может - в названиях каких-то сборников (песенник, задачник, справочник...) или древесных зарослей (ельник, осинник, малинник...). Но если мы встречаем слово птичник, то ни к первой, ни ко второй, ни к третьей группе мы его отнести не можем. Только экстралингвистические знания, наш практический опыт позволят нам семантизировать это слово как «человек, который ухаживает за птицами», или же как «место, где содержатся птицы» (Милославский 1980: 116-117). 
В целом композиционная семантика базируется на когнитивном подходе к языковому значению, на представлении, что в сознании человека активно взаимодействуют знания, закрепленные за языковыми единицами, и знания неязыковые, накопленные благодаря практическому опыту и представленные в концептуальных структурах. В таком случае практические знания, присутствующие в латентном виде в семантике слова, реализуются в высказывании благодаря взаимодействию («композиции») с другими словами. Эти другие слова как бы выбирают нужные элементы из всего семантического потенциала слова.

Скажем, в слове талантливый обнаруживается сема «молодой» (поэтому талантливый музыкант вряд ли будет сказано о 60-летнем человеке), в слове мудрый - сема «опытный, пожилой» (поэтому мудрый педагог звучит нормально, а мудрый ученик - странно), в слове инструмент - сема «мужской» (поэтому типичные инструменты - это молоток и пила, а скалку или пяльцы к инструментам не относят), а в слове брючки - сема «женский» (поэтому про предмет мужской одежды так может быть сказано только сугубо иронически)...

Таким образом, мы убеждаемся в том, что свойство комбинаторики не случайно, оно закономерно отражает специфику концептуализации действительности. Эта мысль высказывается в современной лингвистике по многим конкретным поводам. Так, 3. А. Харитончик, размышляя над особенностями сочетаемости слов (ср.: округлье, стреловидные листья, но не *округлая, стреловидная листва и т.п.), делает совершенно справедливый вывод: «Разная комбинаторика единиц лист (мн. листья) и листва - это убедительное свидетельство разной концептуализации, вычленения неидентичных аспектов одного денотативного пространства. Собирательные значения - это не значения множественного числа, это видение целого, собранного из некоторого числа составляющих элементов» (Харитончик 2015: 110-111).

Возникшая в недрах англистики, композиционная семантика использует метод «эксплицирующей трансформации». В частности, в значении прилагательных выявляются такие скрытые категориальные семы, как «находящийся в», «служащий для», «состоящий из», «имеющий вид», «относящийся к» и т.п. Это типичные предикаты, служащие для систематизации отношений между субстанциями. Возьмем для примера прилагательное лесной. Выражение лесные ягоды мы прочитываем как «ягоды, растущие в лесу», лесная дорога - как «дорога, идущая через лес», лесная промышленность — как «промышленность по переработке леса», лесной техникум - как «техникум, в котором изучают разведение и эксплуатацию леса» и т.д. Иными словами, исследования в области композиционной семантики «вытягивают» на поверхность те знания, которые скрыты в значении лексемы, синтагматически связанной с первым словом (Норман 2013: 205-207). Одновременно выясняется, каким образом взаимодействуют между собой компоненты лексического значения, какие существуют предпосылки для актуализации сем, их экспликации или, наоборот, нейтрализации (погашения).

Что касается реальных процессов речепроизводства и речевосприятия, то носитель языка вынужден то и дело уходить «в сферу здравого смысла»: иначе ему 
пришлось бы неоправданно большое время затрачивать на «дешифровку» словосочетаний. Почему современные масс-медиа пестрят названиями типа фабрика звезд, мельница моды, марафон скидок, барометр профессий, империя пициы c, казалось бы, совершенно «чужими», инородными компонентами фабрика, мельница, марафон, барометр, империя? Потому что носитель языка уже ориентируется в сфере рекламы и заранее догадывается, к чему относятся предлагаемые ему телепрограммы, фестивали или торговые акции. В более сложных ситуациях от читателя или слушателя требуется и более сложная энциклопедическая подкованность. Подтвердим данную мысль одним примером:

(16) В будке, на спине плачущего в гору газона жарили яишницу (Слава Сэ. Сантехник, его кот, жена и другие подробности).

На первый взгляд эта фраза кажется абсурдной (вроде классического образца «Зеленые идеи яростно спят»). Но предложенная автором экспозиция (мужики едут на охоту) позволяет читателю дорисовать остальные подробности, и общий смысл выстраивается примерно такой: 'в будке, в кузове грузовика, с трудом взбирающегося в гору, мужчины жарили яичницу’. Для достижения этого смысла надо знать, что грузовик марки ГАЗ имеет жаргонное название газон, и мощности его двигателя с трудом хватает, чтобы взбираться в гору, и что яичницу можно жарить на плитке с газовым баллоном, прямо в кузове автомобиля, и т.п. При отсутствии этих пресуппозиций читатель, вполне вероятно, и споткнется на приведенной выше фразе.

\section{7. Заключение}

В лексическом значении слова есть составляющая, отвечающая за его вхождение в текст (иначе говоря, ориентированная на создание текста). Она включает в себя поиск (подбор) лексических партнеров слова по синтагматической цепи. В идеале такой партнер представляет собой психологический предикат к уже выбранному слову. Уместно вспомнить здесь пионерскую идею Л.С. Выготского о «чистой предикативности» процесса речепорождения: «Предикативность основная и единственная форма внутренней речи, которая вся состоит с психологической точки зрения из одних сказуемых» (Выготский 1982: 341). Участвующие в этом процессе семы актуализируются - они должны попасть в светлое поле сознания. А в качестве фона и гаранта данного композиционного (комбинаторного) процесса выступает так называемый «здравый смысл», опирающийся на предшествующий опыт человека.

В статье рассмотрены пять языковых ситуаций, имеющих отношение к взаимодействию значения слова с его ближайшим контекстом. Это употребление многозначного слова и сигнализация семантического сдвига, наведение окказионального значения, поведение слова в составе фразеологического сочетания, появление у слова дополнительных коннотаций и расчет на эффект неожиданности.

Общий вывод таков: эволюционное изменение плана содержания лексемы закономерно обнаруживает себя в ее комбинаторике; в этом можно видеть прямую связь когнитивных процессов с механизмами речепорождения. С позиций слуша- 
ющего (адресата), нарушение актуальных правил сочетаемости есть сигнал семантического сдвига в лексическом значении; в то же время можно утверждать, что нетипичная сочетаемость раздвигает когнитивные горизонты, приучает человека к иной (виртуальной) действительности, к иному опыту.

(C) Б.Ю. Норман, 2019 (c) creative

https://creativecommons.org/licenses/by/4.0/

\section{ФИНАНСИРОВАНИЕ И БЛАГОДАРНОСТИ}

Исследование выполнено за счет гранта Российского научного фонда (проект № 16-18-02005).

\section{FINANCE AND ACKNOWLEDGEMENTS}

The research done for this work has been funded by RFBR (project № 16-18-02005).

\section{СПИСОК ЛИТЕРАТУРЫ / REFERENCES}

Бирвиш М. Семантика // Новое в зарубежной лингвистике. Х. М.: Прогресс. С. 177-199. [Birvish, M. (1981). Semantika. Novoe v zarubezhnoi lingvistike. X. (Semantics). Moscow: Progress, 177-199 (In Russ.)]

Влавацкая М.В. Окказиональная синтагматика в функционально-семантическом рассмотрении // Филологические науки. Вопросы теории и практики. Тамбов: Грамота, № 2 (32), Часть 1. C. 39 - 47. [Vlavatskaya, M.V. (2014). Okkazional'naya sintagmatika v funktsional'no-semanticheskom rassmotrenii. Filologicheskie nauki. Voprosy teorii i praktiki. (The occasional syntagmatics in the functional-semantic consideration). Tambov: Gramota, № 2 (32). Chast' 1, 39-47 (In Russ.)]

Выготский Л.С. Мышление и речь // Выготский Л.С. Собрание сочинений. Т. 2: Проблемы общей психологии. М.: Педагогика. С. 5-361. [Vygotskii, L.S. (1982). Myshlenie i rech'. In Vygotskii L.S. Sobranie sochinenij. T. 2: Problemy obshchei psikhologii. (Thinking and speech). Moscow: Pedagogika, 5-361 (In Russ.)]

Гак В.Г. К проблеме семантической синтагматики // Проблемы структурной лингвистики 1971. М.: Наука. C. 367-395. [Gak, V.G. (1972). K probleme semanticheskoi sintagmatiki. In Problemy strukturnoi lingvistiki 1971. (On the problem of semantic syntagmatics). Moscow: Nauka, 367-395 (In Russ.)]

Гаспаров Б.М. Язык, память, образ. Лингвистика языкового существования. М.: Новое Литературное Обозрение. [Gasparov, B.M. (1966). Yazyk, pamyat', obraz. Lingvistika yazykovogo sushchestvovaniya. (Language, memory, image. Linguistics of language being). Moscow: Novoe Literaturnoe Obozrenie (In Russ.)]

Караулов Ю.Н. Активная грамматика и ассоииативно-вербальная сеть. М.: ИРЯ РАН [Karaulov, Yu.N. (1999). Aktivnaya grammatika i assotsiativno-verbal'naya set'. (Active grammar, and associative-verbal network). Moscow: IRYa RAN (In Russ.)]

Кечкеш И. Слово, контекст и коммуникативное значение. Вестник РУДН. Серия: Лингвистика. 2014. № 1. C. 7-18 [Kechkesh, I. (2014). Slovo, kontekst i kommunikativnoe znachenie (Word, Context and Communicative Meaning). Russian Journal of Linguistics, 7-18 (In Russ.)]

Милославский И.Г. Вопросы словообразовательного синтеза. М.: Издательство Московского университета [Miloslavskii, I.G. (1980). Voprosy slovoobrazovatel'nogo sinteza. (Problems of word-formation synthesis). Moscow: Izdatel'stvo Moskovskogo universiteta (In Russ.)] 
Моррис Ч.У. Основания теории знаков // Семиотика. Сост. и ред. Ю.С. Степанова. М.: Радуга. C. 37-89. [Morris, Ch.U. (1983). Osnovaniya teorii znakov. In: Semiotika. Sost. i red. Yu.S. Stepanova. (The foundation of the theory of signs.). Moscow: Raduga, 37—89 (In Russ.)]

Никифорова Е.Б. Изменение сочетаемости лексем как показатель динамики семантической структуры слова // Слово - сознание - культура. Сб. научн. трудов. Сост. Л.Г. Золотых. М.: Флинта - Наука. С. 115-122. [Nikiforova, E.B. (2006). Izmenenie sochetaemosti leksem kak pokazatel' dinamiki semanticheskoi struktury slova. In Slovo - soznanie kul'tura. Sb. nauchn. trudov. Sost. L. G. Zolotykh. (Changes in the compatibility of lexemes as an indicator of the dynamics of the semantic structure of the word). Moscow: Flinta Nauka, 115-122 (In Russ.)]

Норман Б.Ю. Когнитивный синтаксис русского языка. М.: Флинта - Наука [Norman, B.Yu. (2013). Kognitivnyi sintaksis russkogo yazyka. (The cognitive syntax of the Russian language). Moscow: Flinta — Nauka (In Russ.)]

Рахилина Е.В. Когнитивный анализ предметных имен: семантика и сочетаемость. М.: Русские словари [Rakhilina, E.V. (2000). Kognitivnyi analiz predmetnykh imen: semantika i sochetaemost'. (Cognitive analysis of subject names: semantics and compatibility). Moscow: Russkie slovari (In Russ.)]

Сепир Э. Язык. Введение в изучение речи // Сепир Э. Избранные труды по языкознанию и культурологии. М.: Прогресс - Универс. С. 26-203. [Sepir, Е. (1993). Yazyk. Vvedenie v izuchenie rechi. In Sepir E. Izbrannye trudy po yazykoznaniyu i kul'turologii. (Language. An introduction to the study of speech). Moscow: Progress - Univers, 26-203 (In Russ.)]

Стернин И.А. Лексическое значение слова в речи. Воронеж: Издательство Воронежского университета, 1985. [Sternin, I.A. (1985). Leksicheskoe znachenie slova v rechi. (Lexical meaning of the word in speech). Voronezh: Izdatel'stvo Voronezhskogo universiteta (In Russ.)]

Харитончик 3.А. В поисках сущности имен. Сб. научн. ст. Минск: МГЛУ, 2015. [Kharitonchik, Z.A. (2015). V poiskakh sushchnosti imen. Sb. nauchn. st. (Searching for names entity). Minsk: MGLU (In Russ.)]

Aarts, Jan M.G., Calbert, Joseph P. (1979). Metaphor and Non-Metaphor. The Semantics of Adjective Noun Combination. Tübingen: Max Niemeyer Verlag.

Allerton, D.J. (1990). Linguistically Strange Word Combinations. On Strangeness. Ed. by M. Bridges (Swiss Papers in English Language and Literature. 5). Tübingen: Günter Narr Verlag, $25-38$

Asher, Nicholas (2011). Lexical Meaning in Context. A Web of Words. Cambridge University Press.

Gadamer, Hans-Georg (1975). Warheit und Methode. Grundzüge einer philosophischen Methode. (Truth and Method. Basic motions of philosophical method). Tübingen: J.C.B. Mohr. (In Germ.).

Jacobson, Pauline (2014). Compositional Semantics. An Introduction to the Syntax/Semantics. Oxford University Press.

Jones, Steven, Paradis, Carita, Lynne Murphy, M., Willners, Caroline (2007). Googling for 'opposites': a web-based study of antonym canonicity. Corpora. Corpus-based Language Learning, Language Processing and Linguistics, 2 (2), 129-155.

Pustejovsky, James (1996). The Generative Lexicon. 2th printing. Massachusetts: MIT Press.

Sweetser, Eve (1999). Compositionality and blending: semantic composition in a cognitively realistic framework. Cognitive Linguistics: Foundations, Scope and Methodology. Ed. by T. Janssen, G. Redeker. Berlin — New York: Mouton de Gruyter. 129-162.

Turula, Anna (2007). Modyfikujące innowacje frazeologiczne jako amalgamaty znaczeń w świetle modelu dynamicznego opartego na uzusie językowym. Frazeologia a językowe obrazy świata przełomu wieków. Red. naukowy W. Chlebda. Opole: Uniwersytet Opolski. 503-510. 


\title{
Словари и интернет-ресурсы / Dictionaries and Internet Resources
}

БТСРЯ (1998): Большой толковый словарь русского языка. Глав. ред. С.А. Кузнецов. СанктПетербург: Норинт. [BTSRYa: Bol'shoi tolkovyi slovar' russkogo yazyka. Glav. red. S.A. Kuznetsov. (Large Explanatory Russian Dictionary). Saint-Petersburg: Norint (In Russ.)]

Даль В.И. Толковый словарь живого великорусского языка. T. I-IV. Изд. 4-е. Санкт-Петербург - Москва: Т-во Вольф. [Dal' V.I. (1912). Tolkovyi slovar' zhivogo velikorusskogo yazyka. T. I-IV. Izd. 4-e. (Explanatory dictionary of the living great Russian language). SaintPetersburg — Moscow: T-vo Vol'f (In Russ.)].

НКРЯ: Национальный корпус русского языка. URL: www.ruscorpora.ru [NKRYa: Natsional'nyi korpus russkogo yazyka (National corpus of the Russian language)]

Словарь сочетаемости слов русского языка (1983) Под ред. П.Н. Денисова, В.В. Морковкина. Москва: Русский язык [Slovar' sochetaemosti slov russkogo yazyka. Pod red. P.N. Denisova, V.V. Morkovkina. (Dictionary of Russian words compatibility). Moscow: Russkii yazyk (In Russ.)]

Современный русский язык. Социальная и функциональная дифференциация / отв. ред. Л.П. Крысин. М.: ЯСК, 2003. [Sovremennyi russkii yazyk. Sotsial'naya i funktsional'naya differentsiatsiya. Otv. red. L.P. Krysin. (Modern Russian language. Social and functional differentiation). Moscow: YaSK (In Russ.)]

\author{
Article history: \\ Received: 18 January 2019 \\ Revised: 04 March 2019 \\ Accepted: 15 March 2019
}

\section{История статьи:}

Дата поступления в редакцию: 18 января 2019

Дата принятия к печати: 15 марта 2019

\section{Bionote:}

BORIS JU. NORMAN — Doctor of Philology, Professor of the Department of Theoretical and Slavic Linguistics of Belarusian State University (Minsk). Research interests: grammar and lexics of Slavic languages, sociolinguistics, psycholinguistics, cognitive linguistics, linguodidactics. Major (recent) publications: "Basics of Psycholinguistics" (Minsk, 2011), "Cognitive Syntax of the Russian Language" (Moscow, 2013), "New Amusing Russian Language Assignments" (Minsk, 2014), "Life of a Word Form" (Moscow, 2016), "Pragmatic Potential of Russian Lexics and Grammar" (Moscow Yekaterinburg, 2017).

Contact information: e-mail: boris.norman@gmail.com

ORCID: 0000-00018520-5387

\section{Сведения об авторе:}

НОРМАН БОРИС ЮСТИНОВИЧ - доктор филологических наук, профессор, профессор кафедры теоретического и славянского языкознания Белорусского государственного университета (Минск). Сферы научных интересов: грамматика и лексика славянских языков, социолингвистика, психолингвистика, когнитивная лингвистика, лингводидактика. Основные (последние) научные публикации: «Основы психолингвистики» (Минск, 2011), «Когнитивный синтаксис русского языка» (Москва, 2013), «Новые занимательные задачи по русскому языку» (Минск, 2014), «Жизнь словоформы» (Москва, 2016), «Прагматический потенциал русской лексики и грамматики» (Москва - Екатеринбург, 2017).

Контактная информация: email: boris.norman@gmail.com

ORCID: 0000-00018520-5387 